\title{
DIE NEO-MARXISME IN DIE MODERNE TEOLOGIE EN ONS ANTWOORD DAAROP
}

\section{Die aanslae op die Kerk}

Daar is 'n bekende uitspraak van die groot wysgeer Hegel: die geskiedenis leer ons dat die mens niks uit die geskiedenis leer nie. Hoe waar hierdie stelling is, bewys die opmars van die neo-marxisme. Elkeen kan in die geskiedenis die rampsalige gevolge van die wysbegeerte van Karl Marx sien. Die rewolusie wat Marx gepredik het, het al baie van sy eie kinders verslind. Tog was dit vir die neomarxiste geen beswaar om op die spoor van Marx voort te gaan nie. Daar is egter ook teoloë wat nie bereid is om uit die geskiedenis te wil leer nie. Ons ontmoet vandag Karl Marx nie alleen in die filosofie nie, hy is ook 'n gesiene figuur in die teologie. Die nuwere teologie het hom baie nou by die neo-marxisme aangesluit, so nou selfs dat ons kan spreek van 'n huwelik tussen neo-marxisme en moderne teologie, waarby dan opgemerk moet word dat die vryasie, die eerste toenadering veral van die kant van die teologie gekom het.

Die invloed van die neo-marxisme in die teologie vandag is so groot dat ons werklik kan spreek van 'n bedreiging vir die Kerk. Die aanslag van die neo-marxisme op die Kerk in die $20 \mathrm{e}$ eeu is net so groot en gevaarlik as die aanslag van die gnostiek op die Kerk in die eerste eeue na Christus.

In die oudste Christelike Kerk het die gnosis die Kerk wou omarm in ' $n$ dodelike omhelsing. Die gnostiek het gekom met 'n pseudo-evangelie: die mens moet homself verlos deur kennis, insig. Vandag sien ons die dodelike omarming van die neo-marxisme wat tot die Kerk kom met weer 'n pseudo-evangelie: die mens moet homself verlos deur die daad. Die aksent het verskuif van die denke na die daad, maar in wese is dit tog maar altyd dieselfde bedreiging: die mens moet homself verlos.

Ons moet as gelowige Christene en Bybelgetroue teoloë bereid wees om die groot les wat die Kerkgeskiedenis ons leer te aanvaar. Ons kan maar gerus luister na die waarskuwing van Hegel ook al is hy een van die geestelike vaders van die neo-marxisme. Dis my heilige oortuiging dat die Kerk vandag, ook die Geref. Kerk in Suid-Afrika die dreiging van die neo-marxisme op presies dieselfde wyse moet afweer soos die Kerk in die eerste eeue na Christus die aanvalle van die gnostiek weerstaan het.

Al lê die gnostiek die klem op verlossing deur kennis en die neomarxisme op verlossing deur die daad, daar is tog tussen hierdie twee geestesrigtings 'n kenmerkende ooreenkoms. Wat Adolf von Harnack van die gnostiek gesê het, kan vandag met eweveel reg van die neo-marxisme gesê word: die gnostiek was die akute verwêreldliking van die Kerk. ${ }^{1}$ Waar Marx op die preekstoel toegelaat word daar kry ons 'n gesekulariseerde Kerk. 


\section{Die neo-marxisme}

Die neo-marxisme is eintlik 'n wysgerige stroming wat op sy beurt weer die teologie beinvloed het. Ons moet daarom eers kyk na die neo-marxisme in die wysbegeerte anders kan ons sy invloed in die teologie nie verstaan nie. Die neo-marxisme is soos die begrip dit reeds vir ons sê afkomstig van Karl Marx. Daar is egter wel verskil tussen die leer van Marx en die neo-marxisme. Ons kan egter sonder kennis van Marxisme die neo-marxisme nie verstaan nie.

Karl Marx was o.a. 'n leerling van Hegel. Marx het vir sy stelsel uit verskillende bronne geput. Hy is beïnvloed deur Feuerbach, deur die Franse sosialisme, die Engelse klassieke, liberale ekonomie en deur die Joodse toekomsverwagting. Hy het egter baie sterk onder invloed van Hegel gestaan. Marx het by wyse van spreke die idealisme van Hegel uit die hemel na die aarde en uit die gebied van die gees na die terrein van die materie teruggevoer. In sy 11e stelling oor Feuerbach sê Marx: die filosowe het die wêreld op verskillende maniere geinterpreteer, dit word nou tyd om die wêreld te verander.

Marx het godsdiens en metafisika fel bekritiseer. Hy gaan uit van die gedagte dat die lewe in die algemeen en die geskiedenis in die besonder bepaal word deur die materie.

Die maatskaplike syn bepaal die bewussyn van die mens en nie omgekeerd nie. Wat aan die lewe van 'n mens sin en inhoud gee, is nie 'n bo-tydelike, buitewêreldlike, metafisiese waarheid nie, maar dit is ' $\mathrm{krag}$ wat werk in die geskiedenis. Hierdie krag is volgens Marx werksaam via die bane van tese, anti-tese en sintese. ${ }^{2} \mathrm{U}$ hoor hier duidelik die stem van Hegel. Daarom is die geskiedenis volgens Marx 'n geskiedenis van klassestryd en 'n deur rewolusie gekwalifiseerde geskiedenis. ${ }^{3}$

Via rewolusie en diktatuur van die proletariaat sal daar vanself 'n nuwe sosialistiese heilstaat ontstaan. Marx sien die oorsprong van alle ellende in die wêreld in die materiële onderbou, in die sg. maatskaplike strukture waardeur die mens nie werklike mens kan wees nie. Sy felle kritiek op godsdiens en metafisika moet ons verklaar uit die feit dat dit volgens Marx aan die mens ' $n$ ontsnappingsmoontlikheid bied. In sy godsdiens vlug die mens uit die groue ellende van sy daaglikse bestaan na 'n hoëre werklikheid. Marx wil die sg. hoëre werklikheid terugbring in die aardse werklikheid. ${ }^{4}$

Die mens moet volgens Marx verlos word deur afbraak van die bestaande orde en deur opbou van 'n nuwe orde. Hy sien alleen heil vir die mensheid wanneer die bestaande maatskaplike strukture van kapitalisme en uitbuiting van die arbeider afgebreek word en deur volkome ander strukture van 'n klasselose maatskappy vervang word. ${ }^{5}$ Hierdie afbraak- en opbou-idee van Marx is nie heeltemal sy eie uitvinding nie. Hy staan hier in 'n lang humanistiese tradisie wat sy eerste voedingsbodem het in die nominalisme van die Middeleeue wat ook reeds wou afreken met die gedagte dat daar 'n orde is wat van buiteaf die mens opgelê word."

Wel het Marx hierdie idee op 'n eie manier uitgewerk. Marx se idee van afbraak en opbou van die samelewing word bepaal deur 
sy siening op die veranderbaarheid van die dinge. Verander die maatskappy en dan sal die mens vanself ook verander. ${ }^{\top}$ Nuwe strukture gee nuwe mense.

Die leer van Karl Marx het verskillende veranderinge en aanvullings ondergaan. Sy vriend en medewerker Friedrich Engels het byvoorbeeld die marxisme verbind met die evolusieleer van Darwin. Dan is daar die sg. Austromarxisme van Weense sosialiste wat hulle veral besin het op die staat as hefboom tot sosialisme. 'n Bekende uitloper van die marxisme is die neo-marxisme waarvan Ernst Bloch en Herbert Marcuse bekende verteenwoordigers is.

Die neo-marxisme het wel die afbraak-idee van Marx oorgeneem, maar nie sy opbou-idee nie. Die klassieke marxisme het daarom altyd nog 'n regsorde van eie snit gesoek, 'n regsorde wat gerealiseer gaan word aan die einde van die pad van die proletariese rewolusie in 'n klasselose maatskappy. Die neo-marxisme wil egter niks van 'n nuwe orde weet nie. Elke nuwe orde van watter aard ook al, is per definisie korrup. Ernst Bloch het gesê: wat bestaan, kan nie waar wees nie. ${ }^{8}$ Dit geld ook van 'n kommunistiese orde op marxistiese basis. Die rewolusie móét daarom permanent wees.

In sy gerugmakende boek: One Dimensional Man stel Marcuse dit duidelik en omonwonde dat die mens goed is. Saam met Feuerbach en Marx is Marcuse oortuig dat die mens ' $n$ son is wat om homself draai. Tipies hedonisties sien Marcuse die sin van die mens-wees is genot, geluk, plesier. Die mens moet daarom volledig vry wees om te kan geniet. Langs die pad van permanente rewolusie sal die mens as homo laborans tenslotte word tot 'n homo ludens. ${ }^{9}$

Die establishment en die status quo sal egter nooit volledig van die aarde verdwyn nie, want altyd sal iemand moet werk om 'n ander een te laat speel en daarom is die rewolusie permanent. 'n Hel-op-aarde deur arbeid en inspanning bly altyd noodsaaklik om 'n hemel-op-aarde in spel en genot te kan realiseer. ${ }^{10} \mathrm{~S}$. U. Zuidema spreek in hierdie verband van 'n Prometheus-bewind in die filosofie van Marcuse. ${ }^{11}$

\section{Die moderne teologie}

So ver as die ooste verwyder is van die weste, so ver is die neomarxistiese filosofie tog wel verwyder van die teologie. Hoe kan daar dan sprake wees van kontak, selfs van 'n huwelik tussen neomarxisme en teologie? Dit sal vir ons duidelik word wanneer ons let op die diepste motiewe van die moderne of nuwere teologie. Eers moet ons egter sekerheid kry oor die vraag wat met moderne of nuwere teologie bedoel word.

Ek sou die moderne of nuwere teologie wou aandui as die post-Barthiaanse teologie. Soos die dialektiese teologie van Karl Barth as ' $n$ nuwe teologie aangedui is, so kan ons die teologiese ontwikkeling na Barth 'n nuwere teologie noem, omdat hierdie teologie weer met 'n geheel nuwe aanpak en opset gekom het. Ons kan 'n hele paar name noem wat as verteenwoordigers van die nuwere teologie beskou moet word soos byvoorbeeld R. Shaull, R. Cox, J. 
Moltmann, J. B. Metz, D. Sölle, W. A. de Pree, G. H. ter Schegget, H. A. M. Piolet, E. Schillebeeckx, H. Berkhof, H. M. Kuitert e.a.

Onderling is daar groot verskille. Die Gereformeerde Kuitert verskil van die Hervormde Berkhof en die Rooms-Katolieke Schillebeeckx verskil weer van sy Duitse geloofsgenoot Metz. Tog is daar iets gemeenskapliks in hulle aanpak, sodat ons hulle almal onder dieselfde noemer van die nuwere teologie kan bring. Hoewel bogenoemde teoloë onderling soms sterk verskil en mekaar soms heftig bestry, is daar tog 'n gemeenskaplike uitgangspunt ten opsigte van vrae aangaande God, geloof, mens en wêreld.

Ek wil graag sewe kenmerkende eienskappe van die moderne teologie noem. In die eerste plek word die nuwere teologie gekenmerk deur ' $n$ antimetafiese instelling. Die moderne teologie wil graag ' $n$ relevante, eietydse teologie wees en daarom het dit aansluiting gesoek by die denkklimaat van ons tyd. Die denkklimaat van ons tyd word gekenmerk deur die sekularisasie. Ek bedoel dan sekularisasie nie in die sin van die verbrokkeling van die corpus christianum deur die renaissance nie, maar in die betekenis van sekularisme. Dis 'n manier van denke en ook 'n leefwyse waarin God nie meer 'n plek het nie. God as 'n faktor buite hierdie wêreld word nie meer erken nie. God as 'n transsendente, metafisiese God is "dood". God is nie transsendent bo ons nie, maar Hy is ons vooruit in die geskiedenis. God is die God van die toekoms. Daar is dus nie so iets soos ' $n$ transsendensie in ruimte nie maar in die tyd, nie 'n vertikale transendensie nie maar 'n horisontale. ${ }^{12}$ Die aardse werklikheid is die ruimte vir die ontmoeting met God. Dis natuurlik nie so ' $n$ vreemde stelling nie. Ons aanvaar almal dat ons as sondige mense op hierdie geskonde aarde die heilige God kan ontmoet. Dis die diepste vreugde van die geloofservaring. Die nuwere teologie bedoel egter iets anders wanneer daar gespreek word van die aardse werklikheid as die ruimte vir die ontmoeting met God. Gods werklikheid val volledig met onse werklikheid saam. Volgens $H$. A. M. Fiolet is dit selfs heeltemal verkeerd om te praat van 'n ruimte, 'n werklikheid bo ons aardse bestaan waarin God Hom sou bevind. Gods werklikheid val met onse werklikheid saam. ${ }^{13}$

By H. M. Kuitert vind ons met name in sy laaste boek dieselfde gedagte. Hy pleit vir 'n konsekwente horisontalisering van die Christelike geloof. Ons moet die wêreld van God en van sy heil nie buitekant ons wêreld en ons tyd soek nie. Met 'n voorstelling dat God ,buitenwerelds" is, sal 'n mens vandag, aldus Kuitert nie ver kom nie. Nee, ons moet God ,binnenwerelds” ontmoet.14

Saam met 'n binnenwêreldse siening op God gaan 'n aardse siening op die koninkryk van God. En vanselfsprekend bring dit ook 'n nuwe siening op verlossing. Wanneer daar nie 'n ander werklikheid as hierdie aardse werklikheid is nie, dan moét noodwendig die koninkryk van God in hierdie aardse werklikheid gerealiseer word. En verlossing moet dan per konklusie wees 'n aardse verlossing.

Dis dan ook baie duidelik 'n tweede algemene karaktertrek van die nuwere teologie. Ons glo ook dat die koninkryk van God uiteindelik op hierdie aarde gerealiseer gaan word. Daar kom mos ook 
'n nuwe, vernuude aarde. Daar is egter ook 'n vertikale dimensie in die koninkryk van God. Gods nuwe ryk kom van buite, van bo, Gods ryk gaan wel in in hierdie aardse werklikheid, maar val daar hoegenaamd nie mee saam nie.

Die nuwere teologie bepleit egter die volstrekte horisontalisering van die koninkryk van God. Heil, verlossing word daarom vertaal in terme van opheffing van die mens, bevryding van rassisme, kolonialisme en kapitalisme, optimale lewensomstandighede, gelykheid van inkomste, goeie sosiale voorsieninge en degelike.

Saam met hierdie verhorisontalisering van die koninkryk van God gaan ' $n$ nuwe en aanvullende beskouing oor die werk van die Heilige Gees. Dit is 'n derde algemene karaktertrek in die nuwere teologie.

Die Heilige Gees werk in die hart van die mens, die enkele mens, maar daar is ook 'n werk van die Gees van God in die strukture van die samelewing. Ons vind hierdie gedagte diep deurgedink en duidelik uitgesproke by $\mathrm{H}$. Berkhof in sy dogmatiek: Christelijk geloof, waarin hy kom tot 'n sg. "teologie van strukture". Analoog aan die vernuwingswerk van die Gees van God in die gelowige is daar ook ' $n$ vernuwingswerk van die Heilige Gees in die ongelowige waardeur die samelewing verbeter word.

In die Europese kultuur, so skrywe Berkhof, kan 'n mens die werk van die Heilige Gees duidelik opmerk o.a. in die skeiding van regeermag en regspraak, in algemene leerplig, in vryheid van godsdiens, in gelykheid voor die wet e.d.15 Hierdie werk van die Heilige Gees in die samelewing moet volgens Berkhof onderskei word van wat ons noem die voorsienigheid van God soos Sondag 10 van die Heidelbergse Kategismus dit leer en bely.10

Die werk van die Heilige Gees in ongelowiges tot verbetering van die wêreld, tot leefbaarmaking van die aarde, staan in 'n direkte verbinding met die koninkryk van God op aarde.

Sonder Skrifbewys verskuif Berkhof die stryd tussen Gees en vlees wat volgens Paulus tog net gevoer word in in die hart en in die lewe van die gelowige na die wêreld. Die stryd tussen Gees en vlees vind ons, aldus Berkhof ook in die sg. struktuur-gebied waar nie-Christene in hul ywer vir strukturele vooruitgang bots op verset en hardnekkige handhawing van die status quo..17

Hier kry ons by Berkhof 'n gevaarlike splitsing van die siening op die koninkryk van God. Nie-christene kry ook 'n regmatige aandeel naas Christene as objekte van die werk van die Heilige Gees tot realisering van die koninkryk van God op aarde.18

'n Vierde algemene karaktertrek van die nuwere teologie is dat saam met die verskuiwing van die vertikale na die horisontale in die siening op die koninkryk van God ook aan verlossing ' $n$ nuwe konnotasie gegee word.

Die wese van verlossing word meer en meer aards van karakter. Gods heil in Jesus Christus is gerealiseer wanneer sosiale en maatskaplike omstandighede in die samelewing optimaal is. Die wesentlike kern, die harde kern van die versoening met God deur die bloed van Christus verdwyn meer en meer in die moderne teologie. Sonde 
en kwaad moet ons eerder in die strukture van die maatskappy soek as in die hart van die mens. Versoening onder volkere en geregtigheid onder mense kry meer aksent as die versoening met God en die geregtigheid van die geloof.

Hierdie verskuiwing van die vertikale na die horisontale bring ook ' $n$ nuwe siening op die heilsmiddele. Dit is ' $n$ vyfde algemene karaktertrek in die nuwere teologie. Waar die koninkryk van God en ook die koms van die koninkryk verwêreldlik word, daar mót noodwendig ook volg 'n verwêreldliking van die middele waardeur die ryk van God gerealiseer word. Die klem val nie meer so sterk op die werk van die Heilige Gees nie, maar op die aktiwiteit van die mens. Die dunamis van die Gees word ingeruil vir die dinamiet van die landmyne van sg. vryheidvegters.

L. F. Schulze het daarop gewys hoe in die nuwere teologie die verhouding van regverdiging en heiliging skeefgetrek word. Jesus se werk moet deur die mens geverifieer of voortgesit en voltooi word in ons dade van rewolusie en omvorming van strukture. ${ }^{10}$

As sesde karaktertrek van die nuwere teologie kan genoem word die nuwe siening op die mens. Die reformatoriese vertolking van die Bybelse mensbeskouing is ingeruil vir 'n ander mensbeeld. Die Reformasie het die totale korrupsie van die mens geleer. Die moderne teologie staan egter sterk onder invloed van die moderne evolusionistiese wetenskap volgens welke die mens hom van 'n roofprimaat-natuur sprongsgewyse ontwikkel het tot 'n mens wat in vryheid en liefde as God se bondgenoot kan handel. Die sonde kom eintlik uit die dierewêreld te voorskyn en is eerder ons lot as onse skuld.

Ek wil hier graag wys op ' $n$ indringende ontleding van die mensbeskouing in die nuwere teologie deur prof. C. Graafland wat 'n meesterlike analise gegee het van Berkhof se evolusionistiese mensbeskouing. ${ }^{20}$

In die nuwere teologie $0 . a$. by De Pree vind jy die opvatting dat die mens goed is, hy is alleen nog nie gefinaliseer, nie "af" nie. ${ }^{21}$ Maar met name die proletariese mens, die vedrukte mens is goed. Dit lyk of net die kapatalistiese mens in sonde ontvang en gebore is en so verdorwe dat hy onbekwaam is tot enige goed om die maatskappy te verander en geneig tot alle kwaad om homself ten koste van sy medemens te handhaaf.

$U$ sal kan aanvoel dat ' $n$ ander beskouing van die mens en van die sonde ook die Christologie moet beïnvloed. In die nuwere teologie kry ons dan ook 'n ander Jesus-beeld. Dis 'n sewende karaktertrek. In 'n gesprek met $\mathbf{H}$. M. Kuitert het $\mathbf{A}$. A. van Ruler gesê dat in die nuwere teologie Jesus eintlik nie meer as 'n faktor is nie. Hy kan net nog as Voorbeeld, as die groot Rewolusionêr, as „de Partijganger der armen" gepredik word.22

Dit behoef ons nie meer te verbaas nie dat die Kerk deur so ' $n$ Christusprediking verlaag word tot 'n instrument van rewolusie. Die Kerk moet in navolging van Christus partisipeer in die rewolusie en sodoende ontregte mense, vertraptes en gediskrimineerdes steun in hulle rewolusionêre stryd. 


\section{Die huwelik tussen neo-marxisme en nuwere teologie}

In wat ons as tipiese karaktertrekke van die moderne teologie gehoor het, kon ons al sonder veel moeite die neo-marxisme herken. Aan die een kant het die neo-marxisme reeds die nuwere teologie beinvloed, maar andersyds vind ons ook 'n duidelike toenadering van die nuwere teologie tot die neo-marxisme en 'n begeerte om met die neo-marxisme tot 'n dialoog te kom.

Hoe moet ons die verskynsel verklaar dat die nuwere teologie in die greep van die neo-marxisme kon kom? Was die stootkrag van die neo-marxisme so sterk of was die verweer van die nuwere teologie so swak? Die neo-marxisme kon so gemaklik die teologie beïnvloed, omdat die nuwere teologie al sy wapens uit sy hande gegee het.

Dit lyk vir my dat ons drie faktore kan aanwys wat dit vir die neo-marxisme moontlik en gemaklik gemaak het om so diep in die teologie deur te dring $\mathrm{nl}$. die historisme, die sekularisasie en die evolusie.

Die historisme is 'n lewensbeskouing wat die historiese syde van die werklikheid verabsoluteer en wat alle verskynsels probeer herlei tot produkte van 'n historiese ontwikkeling. Veral onder invloed van $\mathrm{E}$. Troeltsch en $\mathrm{W}$. Dilthey het in die einde van die $19 \mathrm{e}$ eeu en in die begin van die $20 \mathrm{e}$ eeu die historisme hom ontwikkel tot 'n lewens- en wêreldbeskouing waarin absolute waarhede en waardes gerelativeer is. ${ }^{23}$

'n Tweede oorsaak kan ons noem die sekularisasie in sy moderne gedaante. Die Westerse kultuur staan nie meer onder invloed van die Woord van God nie. Die ontkerstening van die moderne mens het ongekende vorme aangeneem. Die moderne wetenskap en tegniek het by wyse van spreke die invloed van God uit die samelewing teruggedring. Die profetiese boek van $H$. van Riessen, De maatschappij der toekomst, het dit al in 1952 voorspel. ${ }^{24}$

Die nuwere teologie wou 'n antwoord gee op die uitdaging van die sekularisasie. Maar helaas het die nuwere teologie hom laat vasvang in die probleemstelling van die sekularisasie, want die moderne teologie het sy antwoord laat bepaal deur die vraagstelling van die moderne denke en lewe. Hier wil ek graag wys op die teologie van Paul Tillich. Hy het die metode verdedig dat in die teologie die Bybelse antwoord moet slaan op die menslike vraag. Let wel, die vraag van die moderne mens kom eerste. Dit gaan voorop. Tillich se teologie het bekend geword onder die naam van korrelasie-teologie. Hierdie korrelasie-metode beteken dat die mens deur die wyse waarop hy sy vraag stel, mee die antwoord bepaal. Dit is volgens Tillich onmoontlik om vanuit die Bybel nog ' $n$ antwoord te gee wat buite die vraagstelling omgaan.

Daarom kan 'n man soos Kuitert sê dat daar in ons tyd ander antwoorde uit die Bybel gegee moet word as vroeër byvoorbeeld in die tyd van Paulus of van die Reformasie. ${ }^{25}$

Miskien mag ek dit met 'n voorbeeld uit my eie vakgebied illustreer. Baie teoloë laat hulle by die bestudering van die NT lei 
deur die resultate van die histories-kritiese ondersoek van die Bybel. Dit het hulle tot die konklusie gebring dat die Bybel hoogstens 'n boek van religieuse ervarings kan wees, neerslag van die omgang tussen God en mens as Verbondspartner. Die NT bevat Gods openbaring slegs op indirekte wyse. Wat in die Skrif as heil verkondig word, kom tot ons in die vorm van menslike interpretasies (die van Lukas, Johannes of Paulus byvoorbeeld). Hierdie menslike interpretasie veronderstel denk-, ervarings- en kultuurmodelle wat nie meer onsene is nie en selfs nie meer kan wees nie en waaraan ons dus nie meer gebind kan word nie. Daarom het 'n beroep op die Bybel ook nie meer die laaste woord nie. Paulus spreek byvoorbeeld wel oor versoening, maar dit pas hoegenaamd nie meer in ons denken ervaringsmodelle nie. Ons moet daarom die woord versoening anders ,invul', anders interpreteer, nl. versoening as bevryding. Van hieruit moet $\mathrm{u} \mathrm{H}$. Wiersinga se versoeningsleer verstaan.

In verband met hierdie korrelasie-teologie het $W$. $H$. Velema die fynsinnige opmerking gemaak: „Als de vraag het antwoord structureert, is de vragende mens mede bepalend voor het antwoord". ${ }^{26}$ Om dit op 'n boeremanier te sê: deur hantering van die korrelasiemetode word die teoloog 'n buikspreker. Dit lyk of die geluid uit die Bybel kom, maar dit is altyd die teoloog self wat praat.

Die derde faktor is die moderne evolusionistiese denke. Die leer van die evolusie en die evolusionistiese siening op die mens, mak dit onmoontlik om nog vas te hou aan die Bybelse visie op die mens as die beeld van God. Die dogma van die evolusie het ook baie skade aangerig in die Christologie. Wie uitgaan van 'n evolusionistiese mensbeskouing kan die vere homo van Chalcedon nie meer vashou nie. $^{27}$

Aanhangers van die nuwere teologie wat so diep deur die historisme, die sekularisasie en die evolusieleer beinvloed is, is ' $n$ gemaklike prooi vir die neo-marxisme. Daar sit natuurlik al 'n stuk invloed van die neo-marxisme in die nuwere teologie. Die moderne teologie het baie van haar eie probleme teruggevind in die neomarxisme. Maar aan die ander kant het die nuwere teologie meer en meer toenadering tot die neo-marxisme gesoek. Die nuwere teologie het in die neo-marxisme iets van haarself herken en dit het haar daartoe gebring om die Bybelse boodskap meer en meer te gaan verbuig en vervoeg volgens die grammatika van Karl Marx.

Ons sien hoe voorstanders van die nuwere teologie in hul teologiese besinning meer en meer gebruik gaan maak van die begrippemateriaal van die neo-marxisme om hul eie gedagtes te vertolk.

'n Skoolvoorbeeld is die proefskrif van W. A. de Pree: Maatschappijkritiek en theologiekritiek, 1971, wat uitgaan van die marxistiese probleemstelling. De Pree is ook van oordeel dat die neomarxistiese gedagtes van Ernst Bloch onmisbaar is vir die huidige teologie. Ons moet die Bybel, aldus De Pree, beoordeel onder die gesigspunt van die maatskappyverandering. God as 'n aparte werklikheid bestaan nie. Waar die maatskappy verander, daar ontmoet ons God. ${ }^{28}$ In die teologie van De Pree het die huwelik tussen nuwere 
teologie en neo-marxisme volledig tot stand gekom. Die kind uit hierdie huwelik gebore lyk meer op Karl Marx as op een van die nasate van die Hervormers. Die stem is nog Jakob, die teoloog se stem, maar sy hande is Esau, die marxistiese filosoof se hande. 'n Mens moet wel so blind wees soos Isak om dit nie te kan onderskei nie.

Die invloed van die neo-marxisme in die nuwere teologie is m.i. baie duidelik sigbaar in die siening op die verhouding enkeling - gemeenskap. Sowel die neo-marxisme as die moderne teologie gaan uit van 'n kollektivistiese-sosialistiese samelewingsbeskouing. Die mens is daar ter wille van die gemeenskap. Karl Marx het reeds in navolging van die sosiologiese skool wat juis in sy dae opgang gemaak het, geleer dat die enkele mens primêr deur die samelewing bepaal word. Trouens hier gryp Marx ook terug op Hegel wat reeds geleer het dat ware vryheid eers daar is waar die geheel heers oor die dele. ${ }^{28}$ Wie so 'n stelling aanvaar, kan nie meer weerstand bied aan die kommunisme as sosiaal-ekonomiese orde nie soos ons dit kan sien by P. J. Roscam Abbing. ${ }^{30}$

$\mathrm{U}$ sal besef, broeders, hoe groot die gevaar is wat ons bedreig. Die vyand staan nie alleen voor die grense van die land nie, die vyand is al binne die poorte van Kerk en teologie. Ons word van twee kante aangeval. Diktatoriale politieke sisteme wat uit is op wêreldverowering bedreig ons, maar ook 'n nuwere teologie wat uit is op wêreldverbetering volgens marxistiese norme val op ons aan. Beide vyande, sowel in politiek as in teologie is ten diepste geïnspireer deur Karl Marx.

Is daar wel verweer teen hierdie geweldige aanslae? Goddank, daar is. En dit bring ons by die laaste gedeelte van die titel van ons referaat.

\section{Ons antwoord daarop}

Ek wil saam met $u$ die antwoord gaan soek in die Kerkgeskiedenis. Laat ons bereid wees om wel iets uit die geskiedenis en dan met name uit die Kerkgeskiedenis te wil leer.

Dis my diepgewortelde oortuiging dat ons die dodelike gevaar van die neo-marxisme in Kerk en teologie op presies dieselfde wyse moet bestry soos ons geloofsgenote in die eerste eeue van die Christelike Kerk die gnostiek te lyf gegaan het. Hoe het die oudste Christelike Kerk hom ontworstel aan die greep van die gnostiek?

In die eerste plek deur die goddelike gesag van die O.T. te handhaaf. Dit was die sterke skild gewees teen die aanvalle van 'n religieus sinkretisme. ${ }^{31}$ So moet ook die Kerk in die laaste kwartaal van die 20e eeu die neo-marxisme bestry deur onvoorwaardelik die gesag van die Bybel te handhaaf. Op hierdie punt kan ons niks toegee nie, want anders maak ons ons eie pyle stomp.

' $n$ Tweede kragtige wapen in die hand van die gelowiges in die stryd teen die gnostiek was die belydenis. B. Lohse het in sy boek: Epochen der Dogmengeschichte daarop gewys hoe die Kerk die geloofsbelydenis gebruik het as 'n kragtige wapen teen die heresie. ${ }^{32}$ 
Lohse noem die vasstelling van die kanon van die N.T. die eerste geloofsbelydenis van die oudste Christelike Kerk. ${ }^{33}$ Maar verder wys Lohse ook op die begin van die konfessie van die Twaalf Artikels, die sg. drie artikels oor God, die Vader, die Seun en die Heilige Gees as die tweede geloofsreël van die Kerk wat as 'n wapen gedien het om die bedreiging van die gnostiek te weerlê. ${ }^{34}$ So moet ons ook ons verder uitgeboude konfessie gebruik en hanteer teen die stryd van ons dae om die neo-marxisme in die teologie te bekamp.

'n Derde wapen kan ons noem die regte eksegese volgens die regula fideĩ. ${ }^{35}$ Lohse wys daarop dat die gnostici ook bedrywig was in die eksegese van die Heilige Skrif en daarom het die vroeë Kerk 'n eksegese van die Bybel gesoek volgens ,bestimmte Grundsätzen” en wel volgens die mondelinge owerlewering van die apostels. ${ }^{36}$

Wanneer $u$ dus vra: wat kan-ons doen teen die onstuimige aanvalle van die neo-marxisme in die teologie, dan moet my antwoord wees: eksegese, eksegese. Verklaring van die Heilige Skrif, nie volgens die grammatika van Marx of Ernst Bloch nie, maar volgens die reëls wat in die geskiedenis van die Gereformeerde hermeneutiek altyd as die eerste en belangrikste gegeld het: Sacra Scriptura sui ipsius interpres est, die Heilige Skrif is haar eie tolk of verklaarder.

As vierde wapen wil ek $u$ graag wys op die Gereformeerde teologie. In sy jongste boek: De zaak waarvoor wij staan, sê W. H. Velema dat die Gereformeerde teologie die beste van almal opgewas is teen die vloedgolf van neo-marxisme, omdat hierdie teologie Woord-teologie is. Dit beteken nie dat ons ou dogma's eindeloos gaan herhaal nie, maar dat ons die erfgoed van die Reformasie verder moet uitbou. ${ }^{37}$

Dr. C. Graafland het in die boek: Reformatie: een blijvende opdracht!, 'n baie insiggewende bydrae geskryf onder die titel: De actualiteit van het reformatorisch belijden, waarin hy daarop wys hoe ons op nuwe vrae tog in die teologie van die Reformasie 'n antwoord kan vind, omdat die Reformasie gekenmerk word deur wat Graafland so mooi noem haar "Schriftnabijheid". ${ }^{38}$

Ten slotte wil ek u nog wys op 'n vyfde wapen. In sy klasdiktaat Apologetiek het my kollega prof. L. J. Botha gewys op die getuienis van die gelowiges met woord en daad. Hy skrywe dan: „Vanaf die begin van die Christelike Kerk was en is die belydende gelowiges eintlik die sterkste wapen van die Apologetiek. Elke gelowige Christen moet bereid wees om teenoor al die verkeerde strominge in die wêreld verantwoording te doen van sy geloof. Dit moet hy doen, nie net deur woorde nie, maar veral ook deur 'n vrome lewenswandel wat by die Christelike geloof pas. Daarteen stuit die kragtigste aanvalle van die wêreld en van die dwaalleer". ${ }^{30}$

Dis ons antwoord, sowel in leer as lewenswandel op die aanvalle van die neo-marxisme in die nuwere teologie. Gebruik van hierdie wapens hou in verdediging sowel as aanval. 
En laat ons dit altyd onthou: wie staan aan die kant van die Woord van God, staan aan die kant van die oorwinning!

L. Floor.

(Voordrag gelewer op die G.T.V.-jaarvergadering te Krugersdorp)

1 H. Berkhof: Geschiedenis der kerk, 19474, p. 34.

2 K. Marx: Die Früschriften (Kröners Taschenbuchausgabe Band 209), 1964.

3 W. A. de Pree: Maatschappijkritiek en Theologiekritiek, 1971, p. 139.

4 J. D. Dengerink: Gerechtigheid, Verzoening, Toekomstverwachting, in: Ned. Geref. Teol. Tydskrif, Dl. VXI, No. 4, Sept. 1975, p. 344.

5 J. D. Dengerink: a.a., p. 345, 346.

7 L. Floor: Die Koninkryk van God en die vernuwing van die samelewing, 1974 , p. 27.

8 E. Bloch: Das Prinzip Hoffnung, 1959, p. 143.

9 H. Marcuse: One Dimensional Man, 1966, p. 194.

10 S. U. Zuidema: De revolutionaire maatschappijkritiek van Herbert Marcuse, 1970, p. 196.

11 S. U. Zuidema: a.w., p. 196.

12 L. Floor: Die exodus-motief in die swart teologie, in: Die saailand is die wêreld, 1971, p. 138.

13 H. A. M. Fiolet: Vreemde verleiding, 1968, p. 108.

14 H. M. Kuitert: Zonder geloof vaart niemand wel, 1975\%, p. 90, 91.

15 H. Berkhof: Christelijk geloof, 1973, p. 534.

16 H. Berkhof: a.w., p. 529.

17 H. Berkhof: a.w., p. 535.

18 Bijbelse lijnen voor kerk en samenleving, Rapport van deputate vir Kerk en Samenleving van de Chr. Kerken in Nederland, 1967, p. 11.

19 L. F. Schulze: Die verhouding van regverdiging en heiliging in die moderne teologie, in: In die Skriflig, Jrg. 9, No. 34, Junie 1975, p. 24.

20 C. Graafland: Enkele aspecten van de christelijke geloofsleer bij dr. $\mathbf{H}$. Berkhof, in: Theologia Reformata, Jrg. XIX, No. 1, Maart 1967, p. 50-54.

21 W. A. de Pree: a.w., p. 33, 34. Vgl. A. J. Visser: Karl Marx en Lenin als kerkvaders?, 1975, p. 41.

22 „Konfrontasie met Van Ruler”, in: Rondom het Woord, Theol. Etherleergang, 11e Jrg., No. 1, Febr. 1969, p. 10.

23 K. Heussi: Die Krisis der Historismus, 1932.

24 H. van Riessen: De maatschappij der toekomst, 1952, p. 119, 134, 274.

25 H. M. Kuitert: a.w., p. 104, 105.

26 W. H. Velema: De zaak waarvoor wij staan, 1976, p. 56.

27 C. Graafland: a.a., p. 53.

28 W. A. de Pree: a.w., p. 157, 158.

29 K. J. Kraan: Marx, in: Denkers van deze tijd, 1957, p. 12, 29.

30 W. H. Velema: a.w., p. 182.

31 H. Berkhof: Geschiedenis der kerk, 19474, p. 36.

32 B. Lohse: Epochen der Dogmengeschichte, 1963, p. 42. Vgl. G. Kretschmar: RGG, s.v. Gnosis, Dl. II, 1958, col. 1660.

B. Lohse: a.w., p. $31,32$. 
34 B. Lohse: a.w., p. $40-42$.

35 B. Lohse: a.w., p. 39.

36 B. Lohse: a.w., p. 39, 38.

37 W. H. Velema: a.w., p. 24 e.v.

38 C. Graafland: a.a., p. 15, 27.

\section{BLINDE}

Dis altyd donker en ek moet

my pad maar aanhou tas en voel, waar alles vaag en rooi soos bloed

lyk en ek in die groot gewoel

moet stilhou en gaan staan;

ek wonder soms hoe sal dit lyk

as God opeens die lig aanslaan

en ek die werklikheid bekyk?

Esjee. 